\title{
Serum leucine-enkephalin in bronchial carcinoma and its relation to tumour location
}

\author{
J R Gosney, M A Gosney, Michael Lye
}

\begin{abstract}
Serum concentrations of the opioid peptide leucine-enkephalin were measured by radioimmunoassay in 30 patients with histologically confirmed bronchial carcinoma and 10 control subjects. This peptide, which is present in greatest amounts in the central and autonomic nervous systems, has previously been found in bronchial neoplasms. The mean serum concentration of leucine-enkephalin was significantly greater in the patients with carcinoma $(1035 \mathrm{pg} / \mathrm{ml})$ than in the control subjects $(426 \mathrm{pg} / \mathrm{ml})$. In the 23 patients with a tumour in non-apical regions of the lung, however, the mean concentration of the peptide $(422 \mathrm{pg} / \mathrm{ml})$ did not differ significantly from that in control subjects; serum concentrations in the seven patients with an apical neoplasm (mean 3050 (range 1259-5820) pg/ $\mathrm{ml}$ ) were significantly greater than values in either the control subjects or the patients with non-apical lung tumours. All seven subjects with an apical tumour had one or more features of Horner's syndrome and the three with all four components of the syndrome had the highest serum concentrations. Serum concentrations of leucine-enkephalin were unrelated to tumour type or presence of metastatic disease. No patient had evidence of metastases in the central nervous system or adrenal glands. Raised serum concentrations of leucine-enkephalin in patients with an apical tumour probably reflect invasion of cervical sympathetic ganglia with release of the peptide into the circulation rather than elaboration of the peptide by the neoplasm.
\end{abstract}

Leucine (leu)-enkephalin is one of a group of opioid peptides that includes the closely similar methionine (met)-enkephalin and the endorphins, which are larger peptides structurally related to $\alpha$ lipotrophin. ${ }^{1}$ The physiology and pharmacology of these substances have been extensively researched and their wide distribution in healthy tissues has become apparent. ${ }^{2}$ They are present in greatest amounts in the central and peripheral nervous systems, particularly in the adrenal medulla but also in sympathetic ganglia and in other glomic tissues such as the carotid body. ${ }^{34}$ As with many other peptides, their synthesis by and release from various neuroendocrine neoplasms has been reported ${ }^{5}$ and leu-enkephalin has been detected by immunochemistry in neuroendocrine neoplasms of bronchial origin. ${ }^{6}$ We have measured serum concentrations of leu-enkephalin by radioimmunoassay in a series of patients with histologically proved primary bronchial carcinoma in an attempt to ascertain the prevalence of raised concentrations of this peptide in this condition and its relation to other clinical and pathological features of the disease.

\section{Methods}

Serum concentrations of leu-enkephalin were measured in 30 consecutive patients with bronchial carcinoma confirmed by bronchoscopy and biopsy and in 10 control patients undergoing bronchoscopy who were not found to have a bronchial neoplasm. All patients were clinically examined by one of us (MAG) and the results of all investigations were reviewed and recorded. All had routine haematological and biochemical investigations, including determination of serum alkaline phosphatase activity and other standard tests of hepatic function. Every patient had a plain chest radiograph and in many cases a radiograph of the thoracic inlet. Those with suspected apical lesions underwent tomography. When there was clinical or biochemical suspicion of metastatic disease, appropriate ultrasound and radioisotope scanning was performed. Thoracic radiography and bronchoscopic examination allowed assessment of the site and extent of disease and histopathological examination of tissue biopsy material served to confirm all tumours as of primary bronchial origin. All histopathological material was reviewed by JRG.

In all cases venesection was carried out between 07.00 and 11.00 before bronchoscopy and after an overnight fast, before any centrally acting sedative drugs had been given. All subjects had been awake for at least one hour. None of them had been given any previous treatment likely to affect the nervous system or to interfere with serum enkephalin concentrations. In particular, no patients had been treated with opiates for purposes of analgesia and none was taking any other centrally acting drugs.

Owing to the lability of leu-enkephalin and its sensitivity to protein and salt concentrations, all procedures were performed on crushed ice and all sera reconstituted or diluted with peptone-borate buffer containing merthiolate as a preservative. Blood was taken into \begin{abstract}
cooled plain glass tubes packed in ice and
\end{abstract}
Address for reprint requests: Dr J R Gosney, University Department of Pathology, Royal Liverpool Hospital, iverpool L7 8XP.

Accepted 20 October 1989 
centrifuged at $1700 \mathrm{rev} / \mathrm{min}$ at $4^{\circ} \mathrm{C}$ for 15 minutes before being stored at $-80^{\circ} \mathrm{C}$ until assay. The peptide was measured by a standard radioimmunoassay technique (Incstar Corporation, Minnesota) using iodine-125 labelled leu-enkephalin, anti-leu-enkephalin antibody, and phase separation by saturated ammonium sulphate in the presence of carrier gammaglobulin. Specimens were counted with a Packard Crystal II gamma counter. All samples were assayed in duplicate. Internal quality controls (control sera in which the concentration of leu-enkephalin was known) were included to ensure the validity of results. The sensitivity of the assay system was $100 \mathrm{pg} / \mathrm{ml}$ of leu-enkephalin. Cross reactivity was $100^{\circ}{ }_{0}$ for leu-enkephalin, $1 \cdot 1^{\circ}{ }_{0}$ for methionineenkephalin, and $0.02-1.0 \%$ for the various endorphins.

Sections of tumour tissue were stained with haematoxylin and eosin and labelled for leuenkephalin by the peroxidase-antiperioxidase (PAP) technique, a primary polyclonal antiserum raised in the rabbit being used (Cambridge Research Biochemicals, Cambridge). Sections of rat and human adrenal medulla were used as positive tissue controls.

\section{Statistical methods}

Normality of distribution of the log-transformed serum leu-enkephalin results was confirmed with the Kolmogorov-Smirnov goodness of fit test. Differences between the three groups of patients were assessed by analysis of variance and differences between any two groups by the two tailed Student's test. Results are presented as arithmetic means with standard errors in parentheses and, for the log transformed data, as geometric means.

\section{Results}

In the 10 control patients who underwent bronchoscopy but had no bronchial neoplasm the values for the serum concentration of leuenkephalin ranged from 332 to $565 \mathrm{pg} / \mathrm{ml}$ with a mean of 426 (SEM 21) pg/ml [geometric mean 417]. These values are significantly different from those for the 30 patients with histologically proved bronchial carcinoma ( $p$ $=0.033$ ), which were $218-5820 \mathrm{pg} / \mathrm{ml}$ with a mean of 1035 (252) $\mathrm{pg} / \mathrm{ml}$ [617]. When the patients with carcinoma, however, were divided according to the site of their tumour into "apical" and "non-apical" groups, there was a highly significant difference between control subjects and those with a lesion at the apex $(p<0.001)$, but no significant difference between control subjects and the patients with a non-apical tumour $(\mathrm{p}=0.499)$. The 23 patients with a non-apical tumour had serum values ranging from 218 to $883 \mathrm{pg} / \mathrm{ml}$ with a mean of 422 (33) $\mathrm{pg} / \mathrm{ml} \mathrm{[398];} \mathrm{in} \mathrm{the} \mathrm{seven}$ patients with apical disease values ranged from 1259 to $5820 \mathrm{pg} / \mathrm{ml}$ with a mean of 3050 (648) $\mathrm{pg} / \mathrm{ml}$ [269]. Three of the seven subjects with apical tumours had all the features of Horner's syndrome (miosis, ptosis, anhidrosis, and enophthalmos); the remaining four had ptosis only. The three patients with the complete syndrome had the three highest serum concentrations of leu-enkephalin-5820, 4687, and $3705 \mathrm{pg} / \mathrm{ml}$ (figure).

There was no correlation between histological tumour type and serum concentrations of leu-enkephalin; only two of the seven subjects with an apical tumour had a small cell carcinoma. Of the seven patients with an apical lesion, three had a tumour on the right and four on the left. The distribution of lesions in the 23 patients with non-apical disease was as follows: right main bronchus only, 4; left main bronchus only, 4; left upper lobe, 5; right upper lobe, 2 ; left lower lobe, 4 ; right lower lobe, 2 ; right middle lobe, 1 ; lingula, 1 . There was no relation between the position of the tumour and the serum concentration of leu-enkephalin in these patients with non-apical disease and no correlation between concentrations of leu-enkephalin and the presence or site of metastases. Metastases were evident in only five of the 30 patients with carcinoma (all in bone or liver), including two with apical disease and three with non-apical tumours (serum leu-enkephalin concentrations 393,508 , and $552 \mathrm{pg} /$ $\mathrm{ml})$. There was no correlation between leuenkephalin concentration and sex, age, or duration of disease.

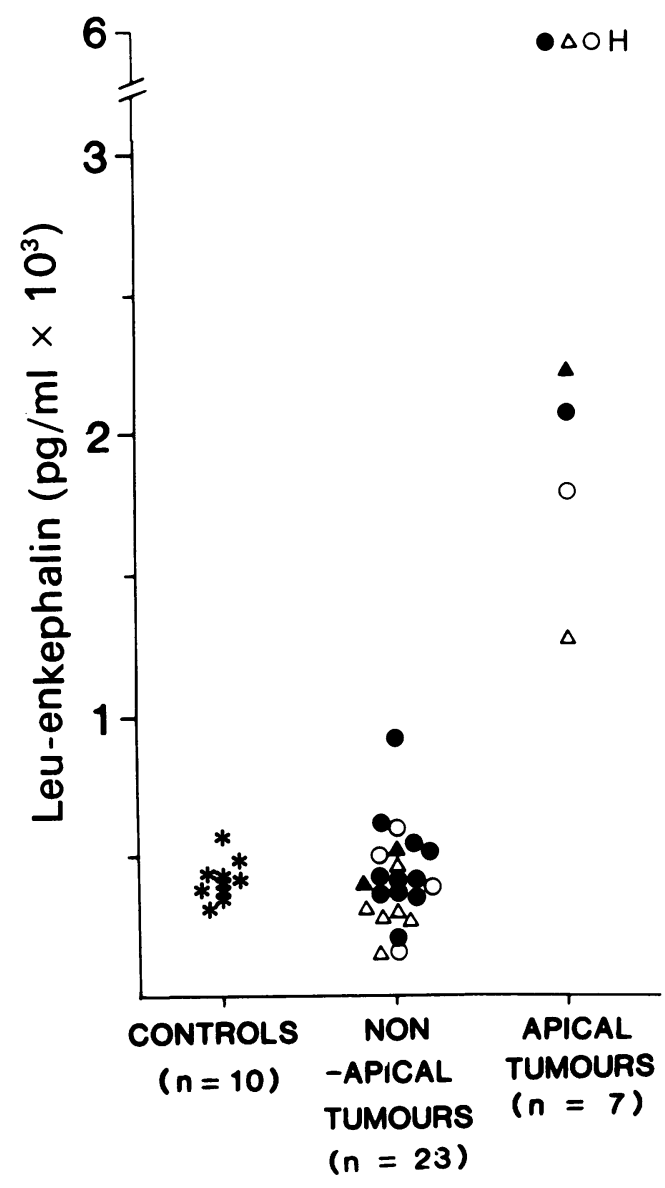

Scattergram showing serum concentrations of leuenkephalin in control subjects and in patients with bronchial carcinoma divided according to the site of the tumour. The seven patients with an apical neoplasm had one or more components of Horner's syndrome; those with the complete syndrome $(H)$ had the highest serum concentrations $(3705,4687$, and $5820 \mathrm{pg} / \mathrm{ml})$.

Squamous carcinoma; $\bigcirc$ adenocarcinoma; $\triangle$ small cell carcinoma; $\Delta$ non-small cell carcinoma; $\star$ no neoplasm. 
Immunochemical examination failed to detect leu-enkephalin in the tissue obtained by bronchoscopy from the tumour of any patient.

\section{Discussion}

Bronchial neoplasms, especially those with neuroendocrine differentiation, have a propensity for elaboration and secretion of peptide hormones, ${ }^{7}$ and leu-enkephalin has been found both within such tumours ${ }^{6}$ and within neuroendocrine cells in the normal human lung. ${ }^{8}$ Increased concentrations of this peptide might therefore be expected in the serum of some patients with bronchial carcinoma. Increased concentrations were found in some patients with lung cancer in our study but this was related to location rather than tumour type. This suggests that the raised concentrations arise from invasion of autonomic ganglia rich in leu-enkephalin, from which the peptide is presumably released rather than from the neoplasm itself. Absence of detectable leu-enkephalin in tissue taken from the tumour at bronchoscopy supports the suggestion that the tissue is not the direct source of the peptide, although small samples of tissue may be unrepresentative of the tumour and rapid secretion of the peptide may leave the tumour depleted of detectable peptide.

We must also consider the possibility that concentrations of leu-enkephalin are increased because other tissues rich in this substance, such as the central nervous system and adrenal glands, are diseased. Release of leu-enkephalin into the cerebrospinal fluid has been described after cerebral infarction in $\operatorname{man}^{9}$ and depletion of the adrenal medulla of this and other neuropeptides has been found in cats after subarachnoid haemorrhage. ${ }^{10}$ Of our seven subjects with an apical lesion and a raised serum concentration of leu-enkephalin, one had metastases in bone and one in liver but none had any evidence, clinically or otherwise, of disease of the central nervous system or adrenals. No subject, irrespective of the site of the neoplasm, had a history of cerebrovascular disease; so we do not believe that release of peptide from these tissues could have been responsible for the raised serum concentrations in our subjects.

We do not know whether the apical tumours were destroying or merely compressing the inferior cervical ganglion and adjacent sympathetic nerves, but destruction of tissue is likely to be required for appreciable amounts of peptide to be released. This would indicate growth of the neoplasm through the pleura and could possibly serve as an aid to staging. We do not know whether invasion of other intrathoracic autonomic tissues, such as the pulmonary plexuses at the root of the lungs, might result in measurable release of peptide, though destruction of a substantial mass of tissue, such as that in the inferior cervical ganglion, might be necessary before sufficient peptide is released for it to be detectable in blood.

Methionine (met)-enkephalin, a pentapeptide differing by only one amino acid from leuenkephalin, is a closely related opioid with a similar distribution. ${ }^{1-4}$ Increased concentrations of met-enkaphalin probably accompany those of leu-enkephalin, both acting as a marker for invasion of the sympathetic chain by neoplasms in the thoracic inlet; but we did not measure met-enkephalin and have no data on this. Nor do we know whether neoplasms that metastasise to the apices of the lungs but are not of bronchial origin would produce the same effect, though this would almost certainly be the case. There is nothing to suggest that the raised serum concentrations of leu-enkephalin we describe is due to anything other than the physical effect of an infiltrating lesion at this particular anatomical site.

This study illustrates the need for circumspection in attributing increased concentrations of substances in the blood of patients with neoplasia to the tumour itself. The strict criteria for establishing a substance as being secreted inappropriately ${ }^{11}$ cannot always be satisfied, and care should be taken to exclude mechanisms such as we describe.

We would like to thank Miss Jill Shaw and Alan Williams for their help in preparing the manuscript. The work was part of a larger study supported by the North West Cancer Research Fund (CR93).

1 Schachter M. Enkephalins and endorphins. Br J Hosp Med $1981 ; 25: 128-36$

2 Thompson JW. Opioid peptides. Br Med J 1984:259-61.

3 Schultzberg M, Hokfelt T, Lundberg JM, Terenius L Elfvin L, Elde R. Enkephalin-like immunoreactivity in nerve terminals in sympathetic ganglia and adrena medulla and in adrenal medullary gland cells. Acta Physiol Scand 1978;103:475-7.

4 Wharton J, Polak JM, Pearse AGE, et al. Enkephalin-, VIPand substance P-like immunoreactivity in the carotid body. Nature 1980;284:269-71.

5 Pullan PT, Clement-Jones V, Corder R, et al. Ectopic production of methionine-enkephalin and betaendorphin. $\mathrm{Br}$ Med J 1980;280:758-9.

6 Warren WH, Memoli VA, Gould VE. Immunohistochemical and ultrastructural analysis of bronchopulmonary neuroendocrine neoplasms. II. Well-differentiated neuroendocrine carcinomas. Ultrastruct Pathol 1984;7:185-99.

7 Greco FA, Hamsworth J, Sismani A. Hormone production and paraneoplastic syndromes. In: Greco FA, Oldham RK, Bunn PA, eds. Small cell lung cancer. New York: Grune and Stratton, 1981:177-224.

8 Cutz E, Chan W, Track NS. Bombesin, calcitonin and leuenkephalin immunoreactivity in endocrine cells of human enkephalin immunoreactivity in end

9 Kobari M, Ishihara N, Yunoki K. CSF beta-endorphin and leu-enkephalin levels in the acute and chronic stages of cerebral infarction. $J$ Neurol 1987;234:289-91.

10 Klein RL, Yabuno N, Peeler DF, et al. Adrenal enkephalin and catecholamine contents following subarachnoid haemorrhage in cats. Neuropeptides 1986;8:143-58.

11 Rees LH, Ratcliffe JG. Ectopic hormone production by nonendocrine tumours. Clin Endocrinol 1974;3:263-99. 